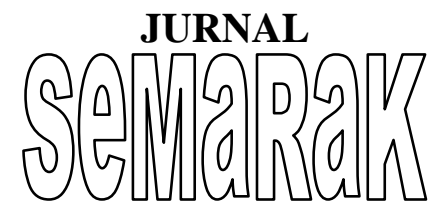

Jurnal Semarak,Vol. 1,No.2,Juni 2018 , Hal (1-20)

@ Prodi Manajemen Fakultas Ekonomi Universitas Pamulang

\title{
ANALISIS PENGARUH EKUITAS MEREK DAN KUALITAS PELAYANAN TERHADAP LOYALITAS PELANGGAN
}

\author{
(Studi Kasus Rumah Sakit Syarif Hidayatullah)
}

\author{
Ahmad Syukri, S.Sos, M.Si \\ Staf Pengajar Fakultas Ekonomi Universitas Pamulang \\ Email: ahmadsyukri360@gmail.com
}

\begin{abstract}
ABSTRAK
Penelitian ini memiliki tujuan untuk menganalisis pengaruh ekuitas merek dan kualitas pelayanan secara simultan terhadap loyalitas pelanggan Rumah Sakit Syarif Hidayatullah, untuk mengetahui pengaruh ekuitas merek dan kualitas pelayanan secara parsial terhadap loyalitas pelanggan Rumah Sakit Syarif Hidayatullah, untuk mengetahui variabel mana yang paling mempengaruhi loyalitas pelanggan pada rumah sakit Syarif Hidayatullah. Dalam penelitian ini menggunakan variabel independen ekuitas merek $\left(\mathrm{X}_{1}\right)$ dan kualitas pelayanan $\left(\mathrm{X}_{2}\right)$. Metode analisis yang digunakan analisa regresi linier berganda. Sampel yang digunakan dalam penelitian ini sebanyak 60 responden yang diambil secara random dari pasien yang menggunakan jasa rumah sakit. Data yang diperoleh merupakan data primer yang merupakan hasil dari jawaban responden atas kuesioner yang disebarkan. Hasil penelitian ini menunjukkan bahwa terdapat pengaruh secara simultan pada variabel merek, kualitas produk, pelayanan, saluran distribusi dan harga terhadap keputusan pembelian. Hasil penelitian ini juga menunjukkan variabel ekuitas merek dan kualitas pelayanan berpengaruh signifikan secara parsial terhadap loyalitas pelanggan. Pada uji determinasi terdapat pengaruh sebesar 74,4\% dari variabel independen (ekuitas merek dan kualitas pelayanan) terhadap variabel dependen (loyalitas pelanggan). Sedangkan, sebanyak 25,6\% dipengaruhi oleh variabel lain dan tidak termasuk kedalam analisis regresi ini.
\end{abstract}

\section{Kata kunci: ekuitas merek, kualitas pelayanan, loyalitas pelanggan}

\begin{abstract}
This research has the purpose to analyze the influence of brand equity and service quality toward customer loyalty simultaneously Syarif Hidayatullah Hospital, to determine the effect of brand equity and service quality on customer loyalty partially Syarif Hidayatullah Hospital, to determine which variables most influence on customer loyalty Syarif Hidayatullah hospital. This research uses brand equity independent variables $\left(X_{1}\right)$ and service quality $\left(X_{2}\right)$. The analysis method using multiple linear regression analysis. The sample used in this research are 60 respondents which drawn at random from patients who use hospital services. The obtained data are primary data that are the result of respondents' answers to the questionnaire distributed.The results of this study indicate that there is a simultaneous effect on the variable of brand equity and service quality toward customer loyalty. The result of the study is also show that the variable of brand equity and service quality take effect significantly in partial toward customer loyalty. In a test of determination, there is an influence of $64.2 \%$ of the independent variables (brand equity and service quality) toward the dependent variable (customer loyalty). Meanwhile, as many as $25.6 \%$ influenced by other variables and not included in this regression analysis.
\end{abstract}

Keywords: brand equity, service quality, customer loyalty.

I. PENDAHULUAN

A. Latar Belakang
Gelombang globalisasi telah menciptakan tantangan bagi rumah sakit 


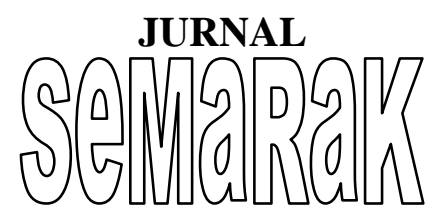

P-ISSN 2615-6849 E-ISSN 2622-3686

Jurnal Semarak,Vol. 1,No.2,Juni 2018 , Hal (1-20)

@ Prodi Manajemen Fakultas Ekonomi Universitas Pamulang yang semakin besar, yaitu kompetisi (competition) yang semakin ketat dan pelanggan (customer) yang semakin selektif dan berpengetahuan. Tantangan seperti ini menghadapkan para pelaku pelayanan kesehatan khususnya rumah sakit baik pihak pemerintah maupun swasta pada dua pilihan, yaitu masuk dalam arena kompetisi dengan melakukan perubahan dan perbaikan atau keluar arena kompetisi tanpa dibebani perubahan dan perbaikan. Oleh karena itu diperlukan alternatif strategi bersaing yang tepat agar perusahaan mampu bersaing dengan kompetitor lainnya. Kondisi lingkungan usaha demikian akan membawa organisasi rumah sakit kepada suatu kenyataan bahwa kualitas dan mutu menjadi suatu keharusan agar perusahaan tetap sukses, baik ditingkat operasional, manajerial maupun strategi.

Semakin tinggi tingkat persaingan bisnis, maka organisasi perusahaan dituntut agar mencapai keunggulan kompetitif (competitive advantage) supaya dapat memenangkan persaingan dalam bisnis. Untuk mencapai hal itu pemasar harus menerapkan konsep pemasaran modern yang berorientasi pelanggan karena mereka merupakan ujung tombak keberhasilan pemasaran (Tjiptono, 2005:100). Rumah sakit sebagai salah satu fasilitas kesehatan merupakan sumberdaya kesehatan yang sangat diperlukan dalam mendukung penyelenggaraan upaya kesehatan yang dicanangkan oleh pemerintah melalui Visi dan Misi Rencana Strategis Depkes tahun 2010 - 2014.

Pada tahun 2008, jumlah rumah sakit di Indonesia mencapai 1.320 rumah sakit (Depkes, 2009), atau bertambah sebanyak 86 rumah sakit dari posisi tahun 2003. Dari total 1.320 rumah sakit ini, 657 diantaranya adalah milik swasta dengan rata-rata pertumbuhan jumlah rumah sakit per tahun sekitar $1,14 \%$. Sisanya merupakan rumah sakit yang dibangun oleh pemerintah (Depkes, Pemprov/Pemkab/Pemkot, TNI/Polri, dan BUMN).

Khusus untuk rumah sakit swasta, tidak sedikit dari rumah sakit yang baru dibangun belakangan ini mengklaim sebagai rumah sakit berstandar internasional. Rumah sakit semacam ini umumnya dilengkapi dengan berbagai peralatan medis canggih terbaru dan fasilitas seperti hotel mewah serta berlokasi di kawasan-kawasan elit perkotaan. Masuknya investor asing, berkembangnya populasi kelas menengah atas, membaiknya tingkat pendapatan perkapita, dan semakin kritisnya masyarakat dalam menjaga kesehatan dan memilih tempat untuk berobat menjadi salah satu alasan peningkatan trend pembangunan rumah sakit kelas atas ini. 


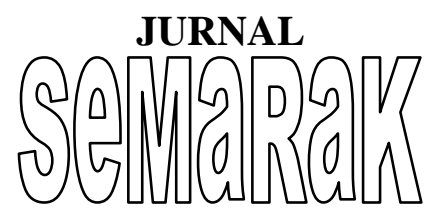

Di samping itu, maraknya pembangunan rumah sakit oleh pihak swasta ini didukung pula oleh semakin aktifnya pemerintah mendorong investasi swasta di bisnis rumah sakit. Pemerintah sendiri telah sejak lama mendukung swasta dan bahkan investor asing untuk berperan dalam pengembangan rumah sakit di Indonesia. Namun, baru melalui Keputusan Presiden tentang Daftar Negatif Investasi (DNI) No. 96 dan No. 118 tahun 2000 pemerintah mengatur bahwa pemodal asing di bisnis rumah sakit Indonesia dapat memiliki kepenguasaan hingga 49\% modal disetor. Hal ini semakin mendorong maraknya pembangunan rumah sakit swasta nasional berjenis joint venture dengan pemodal asing.

Besarnya potensi pengembangan rumah sakit di Indonesia dapat ditunjukkan dari masih tingginya tingkat kebutuhan akan jasa layanan kesehatan yang dapat diukur dari derajat kesehatan masyarakat. Umumnya, derajat kesehatan masyarakat ini diukur dengan beberapa indikator mortalitas seperti Angka Kematian Bayi (AKB), Angka Kematian Balita (AKABA), Angka Kematian Ibu Maternal (AKI), Angka Kematian Kasar (AKK), dan Umur Harapan Hidup Waktu Lahir (UHH). Secara umum, indikatorindikator tersebut telah membaik dari tahun ke tahun, namun angkanya masih cukup tinggi yang menunjukkan masih relatif rendahnya derajat kesehatan masyarakat.

Lebih jauh lagi, potensi kebutuhan rumah sakit di Indonesia dapat ditunjukkan dari masih rendahnya rasio tempat tidur rumah sakit dibandingkan dengan jumlah penduduk. Apabila jumlah tempat tidur rumah sakit di Indonesia mencapai 143 ribu sementara populasi Indonesia mencapai 226 juta (Depkes, 2008), maka perbandingannya adalah sekitar 1: 1.580. Angka ini masih jauh dari rasio ideal yang 1:500 (SWAsembada, 2007). Untuk mencapai rasio ideal tersebut dibutuhkan sedikitnya 451 ribu tempat tidur, dan apabila sebuah rumah sakit memiliki kapasitas rata-rata 200 tempat tidur, maka akan dibutuhkan sedikitnya 2.250 rumah sakit. Bandingkan dengan kondisi Indonesia saat ini yang hanya memiliki 1.320 rumah sakit. Sebagai perbandingan, rasio tempat tidur rumah sakit per-penduduk di Jepang sudah mencapai 1:74 pada tahun 2004, sementara di Malaysia juga sudah mencapai kisaran 1:500 (SWAsembada, 2006). Kondisi ini menunjukkan masih besarnya potensi pengembangan dan pemanfaatan rumah sakit di Indonesia. Sedangkan bila dilihat dari lokasi geografisnya, pengembangan rumah sakit di Indonesia saat ini hanya terkonsentrasi di pulau Jawa. Sekitar 50\% dari total 


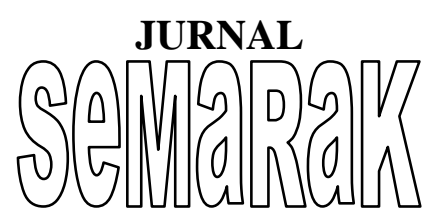

P-ISSN 2615-6849 E-ISSN 2622-3686

Jurnal Semarak,Vol. 1,No.2,Juni 2018 , Hal (1-20)

@Prodi Manajemen Fakultas Ekonomi Universitas Pamulang

rumah sakit di Indonesia berlokasi di pulau Jawa dengan konsentrasi tertinggi terdapat di propinsi Jawa Tengah, Jawa Timur, Jawa Barat dan DKI Jakarta (Depkes, 2008). Dari angka tersebut, sekitar 39\%-nya merupakan milik swasta. Propinsi lain di luar pulau Jawa yang juga memiliki rumah sakit cukup banyak adalah Sumatera Utara dan Sulawesi Selatan.Untuk jumlah pasien, pada tahun 2005 jumlah pasien rumah sakit swasta tercatat mencapai 2,4 juta pasien. Angka ini diproyeksikan akan mencapai 3,5 juta pasien pada tahun 2010, dengan laju pertumbuhan mencapai $7 \%$ per tahun.

Oleh karena banyaknya jumlah pesaing, maka ekuitas merek, kualitas pelayanan, promosi, saluran distribusi, dan tingkat harga produk atau jasa harus benar-benar di perhatikan oleh para pengelola rumah sakit, agar tidak kalah bersaing dengan industri rumah sakit lainnya. Selain itu, pasien merupakan aset yang harus dipertahankan untuk melakukan perbaikan ke dalam pengelolaan rumah sakit. Apalagi, RS Syarif Hidayatullah merupakan rumah sakit yang berbasis pada nilai-nilai Islam sehingga harus betul-betul memerhatikan pelayanan kepada masyarakat.

Loyalitas konsumen dalam pemasaran merupakan hal yang sangat penting untuk diperhatikan. Dalam hal ini perusahaan sangat mengharapkan akan dapat mempertahankan konsumennya dalam waktu yang lama. Sebab apabila perusahaan memiliki seorang konsumen yang loyal, maka hal itu dapat menjadi aset yang sangat benilai bagi perusahaan. Kotler (2000:60) menyatakan bahwa pelanggan yang puas dan loyal (setia) merupakan peluang untuk mendapatkan pelanggan baru.

\section{B. Perumusan Masalah}

Berdasarkan latarbelakang yang telah dikemukakan sebelumnya, maka permasalahan yang akan diajukan dalam penelitian ini adalah:

1. Apakah ekuitas merek dan kualitas pelayanan berpengaruh terhadap loyalitas pelanggan Rumah Sakit Syarif Hidayatullah secara simultan ?

2. Apakah ekuitas merek dan kualitas pelayanan secara parsial berpengaruh terhadap loyalitas pelanggan Rumah Sakit Syarif Hidayatullah ?

3. Variabel independen manakah yang paling mempengaruhi loyalitas pelanggan Rumah Sakit Syarif Hidayatullah ?

\section{Tujuan Penelitian}

Tujuan penelitian ini adalah untuk memberikan jawaban atas pertanyaan khusus di atas. Adapun tujuan penelitian adalah:

1. Untuk menganalisis pengaruh ekuitas merek dan kualitas pelayanan secara simultan terhadap loyalitas pelanggan Rumah Sakit Syarif Hidayatullah 


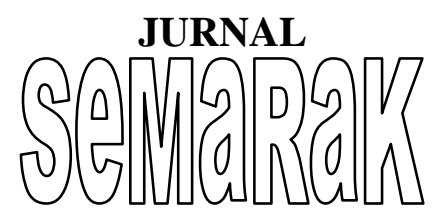

P-ISSN 2615-6849 E-ISSN 2622-3686

Jurnal Semarak,Vol. 1,No.2,Juni 2018 , Hal (1-20)

@Prodi Manajemen Fakultas Ekonomi Universitas Pamulang
2. Untuk mengetahui pengaruh ekuitas merek dan kualitas pelayanan secara parsial terhadap loyalitas pelanggan Rumah Sakit Syarif Hidayatullah.

3. Untuk mengetahui variabel mana yang paling mempengaruhi loyalitas pelanggan pada rumah sakit syarif hidayatullah.

\section{TINJAUAN PUSTAKA}

\section{A. Pengertian Manajemen Pemasaran}

Menurut Kotler yang dimaksud dengan manajemen pemasaran adalah proses perencanaan dan pelaksanaan dari perwujudan, pemberian harga, promosi, dan distribusi dari barang-barang, jasa dan gagasan untuk menciptakan pertukaran dengan kelompok sasaran yang memenuhi tujuan pelanggan dan organisasi (Philip Kolter; 2000:9).

Pemasaran dan produksi merupakan fungsi pokok bagi perusahaan. Semua perusahaan berusaha memproduksi dan memasarkan produk atau jasa untuk memenuhi kebutuhan konsumen. Pada saat ini kegiatan pemasaran mempunya peranan yang sangat penting dalam dunia usaha. Kadang - kadang istilah pemasaran ini diartikan sama dengan beberapa istilah, seperti: penjualan, perdagangan dan distribusi. Pemasaran merupakan konsep yang menyeluruh, sedangkan istilah yang lain tersebut hanya merupakan satu bagian, satu kegiatan dalam sistem pemasaran secara keseluruhan, jadi pemasaran merupakan keseluruhan dari pengertian tentang penjualan, perdagangan dan distribusi (Swastha dan Sukotjo, 2010:178).

\section{B. Pengertian Merek}

Mungkin keahlian paling unik dari pemasar adalah kemampuannya untuk menciptakan, memelihara, melindungi dan meningkatkan merek. Menurut American Marketing Association mendifinisikan merek sebagai berikut: "Brand is a name, term, sign, symbol,or design, or combination of them. Intended to identify the goods or services of one seller or group of seller and to differentiate them from those of competitors" (Kotler, 2003:187).

Selanjutnya Travis

(2009:93) menyatakan bahwa merek tidak hanya merupakan slogan, logo, simbol, ataupun paten. Merek bukan sesuatu yang dibentuk di pabrik melainkan sesuatu yang dibentuk dalam pikiran konsumen melaui proses pemasaran secara keseluruhan. Pemberian merek ditujukan untuk memberikan sesuatu yang unik dan menarik dibandingkan pesaing, sehingga dapat memuaskan kebutuhan konsumen baik secara rasional maupun emosional. Pada saat seseorang memikirkan sebuah produk, mereka hanya mengaitkan dengan atribut serta manfaatnya.

\section{Ekuitas Merek}

\section{a. Pengertian Ekuitas Merek}


JURNAL

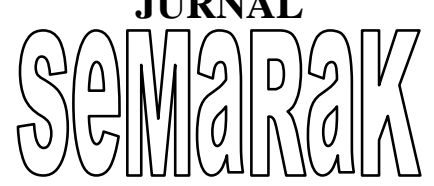

Jurnal Semarak,Vol. 1,No.2,Juni 2018 , Hal (1-20)

@ Prodi Manajemen Fakultas Ekonomi Universitas Pamulang

Dalam sebuah produk harus memiliki merek sebagai sebuah alat pembeda dengan produk lainnya. Sebuah merek akan mengidentifikasikan suatu produk dengan jelas karena dalam merek itu ada hal yang disebut dengan ekuitas merek (brand equity), yang merupakan nilai suatu merek yang bersifat intangible. Mengelola ekuitas merek dapat meningkatkan atribut keunggulan bersaing.

\section{b. Elemen - Elemen Ekuitas Merek}

Menurut Aaker (1991) dalam bukunya dari Tjiptono (2005:40) mengklasifikasikan elemen-elemen ekuitas merek, kedalam lima kategori : loyalitas merek, kesadaran merek, persepsi kualitas, asosiasi merek dan aset merek lainnya. Definisi dan elemen ekuitas merek (brand equity) versi Aaker (1991) dalam Tjiptono (2005:40) ini mengintegrasikan diminsi sikap dan perilaku, sementara kebanyakan operasionalisasi brand equity cenderung hanya berfokus pada salah satu diatara dimensi persepsi konsumen (contohnya, brand awareness, brand association, perceived quality) dan dimensi perilaku konsumen (contohnya, loyalitas merek, kesediaan untuk membayar harga yang lebih mahal) (Cobb-Walgren, Dkk. 1995). a. Kesadaran merek (Brand Awareness)

Menurut Aaker (1991) dalam Tjiptono (2005:40), kesadaan merek adalah kemampuan konsumen untuk mengenali atau mengingat kembali bahwa suatu merek merupakan bagian dari kategori produk terentu. Sedangkan menurut Durianto dkk dalam Kartono (2007:15), kesadaran merek merupakan kesanggupan seorang calon pembeli untuk mengenali, mengingat kembali suatu merek sebagai bagian dari suatu kategori produk tertentu. Berdasarkan definisi diatas dapat disimpulkan bahwa kesadaran merek merupakan kesanggupan seorang calon pembeli untuk mengenali atau mengingat kembali suatu merek sebagi bagian dari suatu kategori produk tertentu.

b. Asosiasi Merek (Brand association)

Menurut Aaker dalam Tjiptono (2005:40), asosiasi merek adalah segala sesuatu yang terkait dengan memori terhadap sebuah merek. Menurut Simamora dalam Kartono (2007:82), menyatakan bahwa asosiasi merek adalah segala hal yang berkaitan tentang merek dalam ingatan. Sedangkan menurut Durianto dkk dalam Kartono (2007:69), asosiasi merek merupakan segala kesan yang muncul dibenak seseorang yang rage | 6 
JURNAL

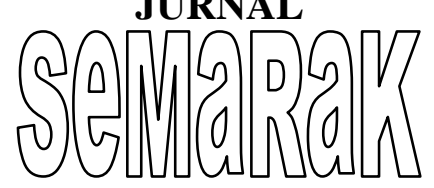

Jurnal Semarak,Vol. 1,No.2,Juni 2018 , Hal (1-20)

@ Prodi Manajemen Fakultas Ekonomi Universitas Pamulang

terkait dengan ingatannya mengenai suatu merek.

c. Persepsi Kualitas (Perceived Quality)

Menurut Aaker dalam Tjiptono (2005:40), persepsi kualitas adalah penilaian pelanggan terhadap keseluruhan kualitas atau keunggulan suatu produk. Simamora (2001:78) menyatakan bahwa persepsi kualitas adalah persepsi pelanggan terhadap kualitas atau keunggulan suatu produk atau jasa layanan ditinjau dari fungsinya secara relatif dengan produk-produk lain. Sedangkan menurut Durianto dkk (2001:96), persepsi kualitas merupakan persepsi pelanggan terhadap keseluruhan kualitas atau keunggulan suatu produk atau jasa layanan berkaitan dengan apa yang diharapkan oleh pelanggan.

d. Loyalitas Merek (Brand Loyalty)

Menurut Rangkuty (2002:60) bahwa, loyalitas merek adalah satu ukuran kesetiaan konsumen terhadap suatu merek. Simamora dalam Kartono (2007:29), menyatakan bahwa loyalitas merek adalah ukuran kedekatan pelanggan pada sebuah merek. Sedangkan menurut Durianto dkk dalam Kartono (2007:126), loyalitas merek merupakan suatu ukuran keterkaitan seorang pelanggan kepada sebuah merek. Berdasarkan definisi diatas dapat disimpulkan bahwa loyalitas merek merupakan ukuran kesetiaan, kedekatan atau keterkaitan pelanggan pada sebuah merek. Ukuran ini mampu memberikan gambaran tentang mungkin tidaknya seorang pelanggan beralih ke merek produk yang lain, terutama jika pada merek tersebut dihadapi adanya perubahan, baik menyangkut harga maupun atribut lainnya.

\section{Kualitas Pelayanan Jasa}

\section{Pengertian Jasa}

Menurut Kotler dan Amstrong (1996) yang dikutip Arief (2007:18), mengemukakan bahwa jasa adalah setiap tindakan atau kegiatan yang dapat ditawarkan oleh suatu pihak kepada pihak lain yang pada dasarnya tidak berwujud dan tidak menyebabkan kepemilikan kepada sesuatu, yang dapat berhubungan dengan suatu produk fisik maupun tidak.

\section{Kualitas Jasa}

Lovelock yang dikutip Wyckop dalam Arief (2007:118), bahwa kualitas jasa adalah tingkat keunggulan yang diharapkan dan pengendalian atas tingkat keunggulan tersebut untuk memenuhi keinginan pelanggan. Dapat disimpulkan bahwa kualitas jasa adalah perbedaan atau ukuran selisih antara 
JURNAL

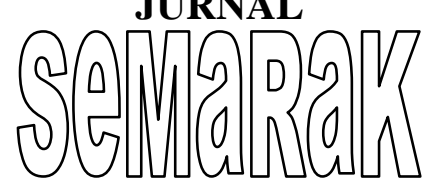

Jurnal Semarak,Vol. 1,No.2,Juni 2018 , Hal (1-20)

@ Prodi Manajemen Fakultas Ekonomi Universitas Pamulang

harapan pelayanan yang akan diterima oleh konsumen dengan pelayanan yang telah diberikan oleh penyedia jasa.

\section{Karakteristik Jasa}

Menurut Zeithaml dan Berry yang dalam Arief (2007:19), Secara umum jasa mempunyai beberapa karakteristik khusus dengan barang. Jasa mempunyai pengaruh besar dalam pemasarannya, yaitu tidak berwujud, tidak dapat dipisahkan antara proses produksi dengan konsumsi, mempunyai variabelitas yang tinggi, tidak dapat disimpan dan tidak menyebabkan suatu kepemilikan.

\section{Tolak Ukur Kualitas Jasa}

Pasuraman, Zeithaml dan Berry dalam Arif (2007:130) menyatakan bahwa sepuluh dimensi tersebut dapat disederhanakan menjadi lima dimensi yang perlu diperhatikan untuk menyatakan pengukuran kualitas jasa.

Sebagai berikut:

a. Tangible (Kasat Mata)

Kualitas pelayanan berupa sarana fisik perkantoran, komputerisasi, administrasi, ruang tunggu, tempat informasi dan sebagainya.

b. Reliability (Keandalan)

Kemampuan dan keandalan untuk menyediakan pelayanan yang terpercaya.

c. Responsiviness (Daya Tanggap)
Kesanggupan untuk membantu menyediakan secara cepat dan tepat serta tanggap pada keinginan pelanggan.

d. Assurance (Jaminan)

Kemampuan dan memberikan rasa aman serta keramahan dan sopan santun pegawai dalam meyakinkan kepercayaan oleh pelanggan.

e. Empathy (Empati)

Untuk mengukur kemampuan pemahaman karyawan terhadap kebutuhan oleh konsumen serta perhatian yang akan diberikan karyawan.

\section{E. Loyalitas Pelanggan}

\section{Pengertian Loyalitas Pelanggan}

Menurut Tjiptono (2000:110) loyalitas merupakan komitmen pelanggan terhadap toko, merek ataupun pemasok yang didasarkan atas sikap positif yang tercermin dalam bentuk pembelian berulang secara konsisten. Loyalitas menurut Pawitra (dalam Usahawan, 1996:23) adalah komitmen pelanggan terhadap suatu leveransir karena memperoleh kepuasan pada saat pembelian, dan kesetiaan ini ditunjukkan dalam bentuk sikap yang menguntungkan.

\section{Tahap - Tahap Loyalitas}

Dalam kontek bisnis, loyalitas dijelaskan sebagai keinginan konsumen untuk berlangganan pada perusahaan Page | 8 
JURNAL

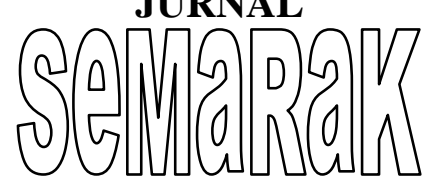

Jurnal Semarak,Vol. 1,No.2,Juni 2018 , Hal (1-20)

@Prodi Manajemen Fakultas Ekonomi Universitas Pamulang

terus menerus membeli dan menggunakan produk dan jasa perusahaan berulang kali dan merekomendasikan produk perusahaan kepada orang lain. Lovelock dan Wirtz dalam (Wahyuni 2009:39) mengatakan bahwa pada mulanya konsumen akan mengalami:

a. Loyalitas Kognitif (Keyakinan)

Konsumen yang mempunyai loyalitas tahap pertama ini menggunakan basis informasi yang secara memaksa menunjuk pada suatu merek atas merek yang lainnya.

b. Loyalitas Afektif (Sikap)

Konsumen membangun kesukaan terhadap brand berdasarkan penggunaan yang terkumulatif. Tingakat kesukaan konsumen harus lebih tinggi daripada merek saingan, sehingga terdapat preferensi yang jelas pada merek fokal.

c. Loyalitas Konatif (Niat Konsumen Terhadap Merek)

Konatif merupakan suatu niat atau berkomitmen untuk dapat melaksanakan sesuatu kearah suatu tujuan tertentu. Niat mencapai fungsi berawal dari niat sebelumnya dan sikap pada masa pasca konsumsi. Maka loyalitas konatif merupakan suatu kondisi loyal yang mencakup komitmen mendalam untuk melakukan pembelian.

d. Loyalitas Action (Tindakan)
Pada tahap ini merupakan tahap tertinggi pada loyalitas konsumen karena tingkat kesetiaan yang sudah kuat dan ditandai dengan motivasi yang kuat dan tercermin dalam keinginan untuk melakukan tindakan dalam mengatasi segala halangan yang mungkin dapat mempersulit konsumen tersebut untuk membeli merek yang diinginkannya.

\section{Tipe - Tipe Loyalitas Konsumen}

Dari uraian di atas maka loyalitas mencakup dua komponen yang penting, yaitu berupa loyalitas sebagai perilaku dan loyalitas sebagai sikap. Kombinasi dari dua komponen tersebut maka akan menghasilkan 4 (empat) situasi kemungkinan loyalitas, no loyality, latent loyality dan loyality.

\section{Faktor - Faktor Yang dapat Mempengaruhi Variabel Loyalitas Pelanggan}

Menurut studi yang dilakukan WARS (SWA, 2005) dalam Saepul Anwar, 2008:33) ada lima faktor yang menyebabkan konsumen loyal pada merek yang digunakannya yaitu:

a. Nilai merek (brand value) yaitu persepsi konsumen yang membandingkan antara biaya atau harga yang ditanggung dan manfaat yang diterimanya.

b. Karakteristik konsumen (customer characteristic) yaitu karakter konsumen dalam menggunakan 
JURNAL

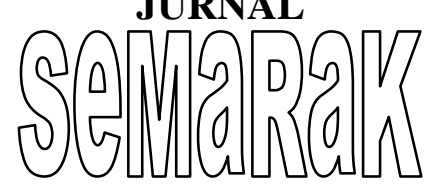

Jurnal Semarak,Vol. 1,No.2,Juni 2018 , Hal (1-20)

@Prodi Manajemen Fakultas Ekonomi Universitas Pamulang

merek. Kenyataannya, setiap individu memiliki karakteristik yang berbeda dari individu yang lainnya.

c. Hambatan pindah (switching barrier) yaitu hambatan-hambatan atau biaya yang harus ditanggung konsumen bila ia akan pindah dari suatu merek ke merek lain.

d. Kepuasan kunsumen (consumer satisfaction) yaitu berkaitan dengan pengalaman konsumen ketika melakukan kontak dengan merek yang digunakannya.

e. Lingkungan yang kompetitif (competitive environment) yaitu menyangkut sejauh mana kompetitif yang menjadi antara mereka dalam satu kategori produk.

\section{F. Hipotesis Penelitian}

Berdasarkan kerangka pemikiran diatas sesuai dengan tujuan penelitian untuk menjawab pertayaan penelitian, maka hipotesis yang diuji adalah sebagai berikut:

1. $\mathrm{H}_{\mathrm{a}}$ : Terdapat pengaruh secara simultan antara ekuitas merek dan kualitas pelayanan terhadap loyalitas pelanggan

$\mathrm{H}_{\mathrm{o}}$ : Tidak Terdapat pengaruh secara simultan antara ekuitas merek dan kualitas pelayanan terhadap loyalitas pelanggan

2. $\mathrm{H}_{\mathrm{a}}$ : Terdapat pengaruh secara parsial ekuitas merek terhadap loyalitas pelanggan
$\mathrm{H}_{\mathrm{o}}$ : Tidak Terdapat pengaruh secara parsial antara ekuitas merek terhadap loyalitas pelanggan

3. $\mathrm{H}_{\mathrm{a}}$ : Terdapat pengaruh secara parsial kualitas pelayanan terhadap loyalitas pelanggan

$\mathrm{H}_{\mathrm{o}}$ : Tidak Terdapat pengaruh secara parsial antara kualitas pelayanan terhadap loyalitas pelanggan

\section{METODE PENELITIAN}

Lokasi dalam penelitian ini adalah Rumah Sakit Syarif Hidayatullah Jakarta yang berlokasi di Tangerang Selatan, Banten. Metode yang digunakan dalam penelitian ini adalah metode studi kasus yang merupakan salah satu penelitian deskriptif, dengan studi ini diharapkan dapat diungkap secara mendalam variabel-variabel yang akan dapat menggambarkan tentang analisis ekuitas merek dan kualitas pelayanan jasa terhadap loyalitas pelanggan.

Data yang digunakan adalah menggunakan data primer dan data skunder. Data primer yang berupa wawancara beberapa dan berupa penyebaran kuesioner sedangkan dari data sekunder berupa keadaan umum objek penelitian (Rumah Sakit Syarif Hidayatullah Jakarta).

Teknik pengambilan sampel yang akan diambil dalam penelitian ini adalah metode non probability sampling dimana sampel yang akan diambil sudah 


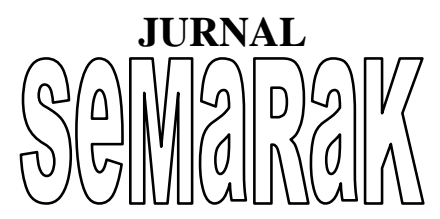

P-ISSN 2615-6849 E-ISSN 2622-3686

Jurnal Semarak,Vol. 1,No.2,Juni 2018 , Hal (1-20)

@Prodi Manajemen Fakultas Ekonomi Universitas Pamulang

ditentukan terlebih dahulu kriterianya

(Husein Umar, 2010:159). Peneliti mencoba menarik anggota populasi untuk menjadi sampel berdasarkan kemudahan ditemui atau ketersediaan anggota populasi yang sudah ditentukan atau dengan metode convinience sampling (Husein Umar, 2010:160). Ukuran sampel yang layak dalam penelitian adalah antara 30 sampai 500 (Sugiono, 2010:52).

Teknik pengumpulan data dengan menggunakan wawancara dan observasi serta kuesioner. Sampel yang dijadikan objek penelitian sebanyak 60 orang pasien dan keluarga pasien pada Rumah Sakit Syarif Hidayatullah Jakarta.

\section{HASIL DAN PEMBAHASAN}

\section{A. Gambaran Umum Rumah Sakit Syarif} Hidayatullah

\section{Sejarah Rumah Sakit Syarif Hidayatullah}

Rumah sakit syarif hidayatullah adalah rumah sakit swasta yang telah melayani masyarakat sejak tahun 1961. Berawal dari sebuah klinik kecil dilingkungan UIN (IAIN) yang kemudian berkembang menjadi rumah sakit swasta pertama ditahun 2007. Lokasi rumah sakit di Jl. Ir. Djuanda No. 95 Ciputat.

Berdirinya Rumah Sakit Syarif Hidayatullah (RSSH) diawali dari adanya sebuah kebutuhan dikalangan mahasiswa dan pegawai IAIN (sekarang UIN) beserta keluarganya terhadap pelayanan kesehatan diwilayah Ciputat yaitu, 1) corp Kesehatan Mahasiswa 1962, 2) Bediri Sebuah BKIA Dan RB 1969, 3) PUSKES IAIN, yang Dikelola IAIN 1976, 4) PUSKES IAIN, yang Dikelola Yayasan 1986, 5) Klinik Syarif Hidayatullah 1990, 6) Rumah Sakit Syarif Hidayatullah 2007.

\section{Visi Dan Misi Rumah Sakit Syarif} Hidayatullah Jakarta

a. Visi:

1) Menjadi rumah sakit yang bernuansa islam yang memiliki citra positif dan mampu memberikan pelayanan secara paripurna kepada masyarakat.

b. Misi:

1) Melaksanakan integralisasi nilai Islam keseluruh aspek manajemen pelayanan.

2) Mengembangkan sumberdaya manusia islami yang tangguh, handal dan berahlak mulia.

3) Mengupayakan kepuasan dan kesan yang mendalam kepada pelanggan yang dilakukan secara berkelanjutan.

4) Memberikan dukungan dalam penyediaan dalam hal fasilitas pendidikan dan pelatihan dibidang medis / kesehatan kepada masyarakat. 
JURNAL

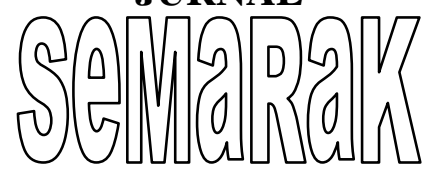

P-ISSN 2615-6849 E-ISSN 2622-3686

Jurnal Semarak,Vol. 1,No.2,Juni 2018 , Hal (1-20)

@Prodi Manajemen Fakultas Ekonomi Universitas Pamulang
5) Menjadi bagian integral dari jaringan pelayanan kesehatan nasional.

\section{B. Penemuan dan Pembahasan}

\section{Hasil Uji Validitas dan Reabilitas}

Sebelum kuisioner diberikan kepada 60 responden, penulis melakukan try out terhadap 20 responden dengan memberikan 33 butir pertanyaan untuk menguji tingkat validitas dan reliabilitas dari seluruh pernyataan tersebut. Kuesioner dibagi menjadi tiga variabel utama, yaitu ekuitas merek, kualitas pelayanan, dan loyalitas pelanggan. Kuesioner dilakukan setelah penulis melakukan try out terhadap 20 responden.

\section{Tabel 1}

Instrumen Ekuitas Merek $\left(\mathrm{X}_{1}\right)$

\begin{tabular}{|c|c|c|c|c|}
\hline $\begin{array}{c}\text { Item } \\
\text { Pertanyaan }\end{array}$ & $\begin{array}{c}\text { Corrected } \\
\text { Item-Total } \\
\text { Correlation }\end{array}$ & Keterangan & $\begin{array}{c}\text { Alpha } \\
\text { Cronbach's }\end{array}$ & Keterangan \\
\hline EMl & 0,709 & Valid & 0,930 & Reliabel \\
\hline EM2 & 0,686 & Valid & 0,930 & Reliabel \\
\hline EM3 & 0,688 & Valid & 0,930 & Reliabel \\
\hline EM4 & 0,881 & Valid & 0,923 & Reliabel \\
\hline EM5 & 0,823 & Valid & 0,926 & Reliabel \\
\hline EM6 & 0,766 & Valid & 0,928 & Reliabel \\
\hline EM7 & 0,613 & Valid & 0,933 & Reliabel \\
\hline EM1 & 0,696 & Valid & 0,930 & Reliabel \\
\hline EM9 & 0,613 & Valid & 0,933 & Reliabel \\
\hline EM10 & 0,615 & Valid & 0,932 & Reliabel \\
\hline EMl1 & 0,818 & Valid & 0,926 & Reliabel \\
\hline EM12 & 0,678 & Valid & 0,931 & Reliabel \\
\hline EM13 & 0,587 & Valid & 0,935 & Reliabel \\
di1 & IS
\end{tabular}

merek pada EM 1-13 mempunyai nilai $\mathrm{r}_{\text {hitung }}$ lebih besar dari 0,3 sehingga item pertanyaan tersebut adalah valid dan reliable.

Tabel 2

Instrumen Kualitas Pelayanan $\left(\mathbf{X}_{2}\right)$

\begin{tabular}{|c|c|c|c|c|}
\hline $\begin{array}{c}\text { Item } \\
\text { Pertanyaan }\end{array}$ & $\begin{array}{c}\text { Corrected } \\
\text { Item-Total } \\
\text { Correlation }\end{array}$ & Keterangan & $\begin{array}{c}\text { Apha } \\
\text { Cronbach's }\end{array}$ & Keterangan \\
\hline KP1 & 0,866 & Valid & 0,939 & Reliabel \\
\hline KP2 & 0,853 & Valid & 0,940 & Reliabel \\
\hline KP3 & 0,752 & Valid & 0,941 & Reliabel \\
\hline KP4 & 0,625 & Valid & 0,945 & Reliabel \\
\hline KP5 & 0,749 & Valid & 0,942 & Reliabel \\
\hline KP6 & 0,853 & Valid & 0,940 & Reliabel \\
\hline KP7 & 0,689 & Valid & 0,943 & Reliabel \\
\hline KP3 & 0,651 & Valid & 0,945 & Reliabel \\
\hline KP9 & 0,866 & Valid & 0,939 & Reliabel \\
\hline KP10 & 0,678 & Valid & 0,943 & Reliabel \\
\hline KP11 & 0,752 & Valid & 0,941 & Reliabel \\
\hline KP12 & 0,65 & Valid & 0,945 & Reliabel \\
\hline
\end{tabular}

Dari hasil output di atas dapat dilihat untuk butir pertanyaan kualitas pelayanan pada KP 1 - 14 mempunyai nilai $r_{\text {hitung }}$ lebih besar dari 0,3 sehingga item pertanyaan tersebut adalah valid dan reliabel.

\section{Tabel 3}

Instrumen Loyalitas Pelanggan (Y)

\begin{tabular}{|c|c|c|c|c|}
\hline $\begin{array}{c}\text { Item } \\
\text { Pertanyaan }\end{array}$ & $\begin{array}{c}\text { Corrected } \\
\text { Item-Total } \\
\text { Correlation }\end{array}$ & Keterangan & $\begin{array}{c}\text { Alpha } \\
\text { Cronbach's }\end{array}$ & Keterangan \\
\hline LY1 & 0,801 & Valid & 0,842 & Reliabel \\
\hline LY2 & 0,691 & Valid & 0,858 & Reliabel \\
\hline LY3 & 0,648 & Valid & 0,866 & Reliabel \\
\hline LY4 & 0,632 & Valid & 0,879 & Reliabel \\
\hline LY5 & 0,750 & Valid & 0,848 & Reliabel \\
\hline LY6 & 0,677 & Valid & 0,861 & Reliabel \\
\hline
\end{tabular}

\section{Hasil Uji Asumsi Klasik}

\section{a. Hasil Uji Normalitas Data}

Data-data bertipe skala pada umumnya mengikuti asumsi distribusi normal. Namun, tidak mustahil suatu data tidak mengikuti asumsi normalitas. Untuk mengetahui kepastian sebaran data yang diperoleh harus dilakukan uji normalitas terhadap data yang bersangkutan. Dengan demikian, analisis statistika yang pertama harus digunakan dalam rangka analisis data adalah analisis statistik berupa uji normalitas.

\section{Gambar 1}


Jurnal Semarak,Vol. 1,No.2,Juni 2018 , Hal (1-20)

@Prodi Manajemen Fakultas Ekonomi Universitas Pamulang

\section{Hasil Uji Normalitas Data Secara Grafik}

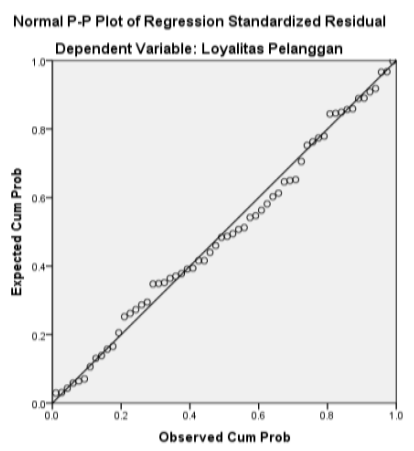

Dari grafik di atas dapat dilihat bahwa data penelitian memiliki penyebaran dan distribusi yang normal karena data memusat pada nilai rata-rata dan median atau nilai plot PP terletak digaris diagonal, maka dapat dikatakan bahwa data tersebut berdistribusi normal.

Untuk menegaskan hasil uji normalitas di atas maka peneliti melakukan uji kolmogorov-smirnov dengan hasil sebagai berikut:

Tabel 4 Hasil Uji Normalitas Data Secara Statistik

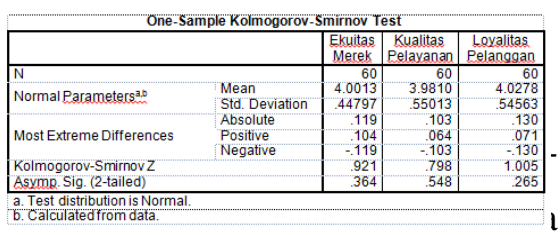

seluruh variabel memiliki nilai sig. > 0,05 , ini mengartikan bahwa semua data terdistribusi dengan normal.

\section{b. Hasil Uji Multikolinearitas}

Hasil Uji multikolinearitas diperlukan untuk mengetahui ada tidaknya variabel independen yang memiliki kemiripan dengan variabel independen lain dalam satu model atau terdapat hubungan yang kuat diantara variabel independen di dalam model.

Tabel 5

Hasil Uji Multikolinearitas

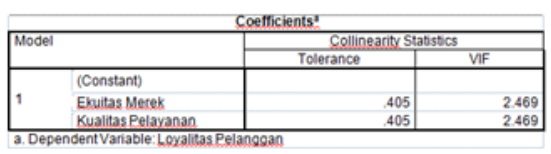

Berdasarkan pada tabel di atas terlihat bahwa nilai Tolerance tidak kurang dari 0,10 dan nilai Varian Inflation Factor (VIF) tidak lebih dari 10, analisis ini dapat disimpulkan bahwa model regresi linier berganda terbebas dari asumsi klasik statistik dan dapat digunakan dalam penelitian.

\section{c. Hasil Uji Heteroskedastisitas}

Hasil uji heteroskedastisitas menunjukan bahwa variasi variabel tidak sama untuk semua pengamatan. Pada hasil uji heterokedastisitas kesalahan yang terjadi tidak secara acak tetapi menunjukan hubungan yang sistematis sesuai dengan besarnya satu atau lebih variabel. Berdasarkan hasil pengolahan data, maka hasil Scatterplot dapat dilihat pada gambar berikut:

\section{Gambar 2}

Hasil Uji Heteroskedastisitas

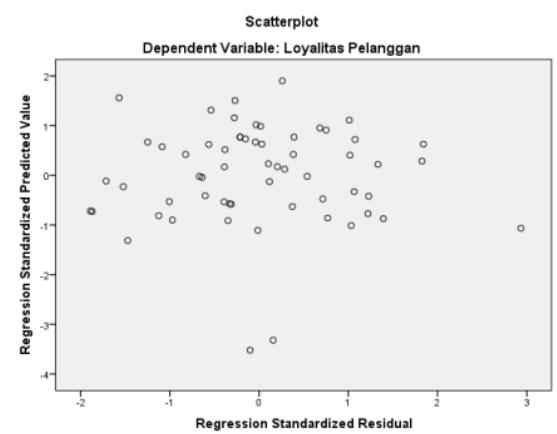


JURNAL

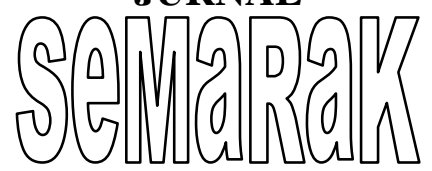

P-ISSN 2615-6849 E-ISSN 2622-3686

Jurnal Semarak,Vol. 1,No.2,Juni 2018 , Hal (1-20)

@ Prodi Manajemen Fakultas Ekonomi Universitas Pamulang
Pada gambar di atas menunjukkan tidak terjadi pola tertentu yang teratur seperti bergelombang, melebar, dan lainlain. Sesuai dengan pedoman uji heteroskedastisitas, maka dalam penelitian ini tidak terjadi heteroskedastisitas atau disebut homokedastisitas. Hal ini dibuktikan dengan grafik plot diatas yang tidak membentuk pola tertentu yang teratur sehingga penelitian ini layak dilakukan pengujian lebih lanjut.

\section{Hasil Uji Hipotesis Penelitian}

\section{a. Hasil Uji Signifikansi Simultan} (Uji Statistik F)

Pengujian hipotesis secara simultan bertujuan mengukur ada atau tidaknya pengaruh variabel bebas secara bersama-sama terhadap variabel terikatnya. Hasil hipotesis yang dalam pengujian ini adalah:

Tabel 6 Hasil Uji F

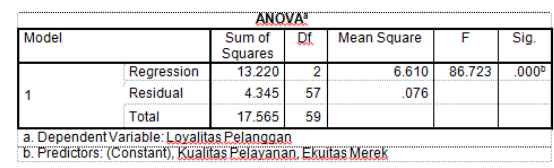

Berdasarkan tabel di atas analisis varian (Anova) ditampilkan hasil uji $F_{\text {hitung }}$ yang dapat dipergunakan untuk memprediksi kontribusi aspek-aspek variabel ekuitas merek dan kualitas pelayanan terhadap variabel loyalitas pelanggan. Dari penghitungan didapat nilai $F_{\text {hitung }}$ sebesar 86,723 dengan tingkat signifikansi sebesar $5 \%$ dan $\mathrm{df}_{1}=2$ dan $\mathrm{df}_{2}=57$, didapat nilai $\mathrm{F}_{\text {tabel }}=$ 3,16. Karena nilai $F_{\text {hitung }}(86,723)>$ nilai $F_{\text {tabel }}(3,16)$ maka dapat disimpulkan bahwa kedua variabel independen yaitu ekuitas merek dan kualitas pelayanan memiliki pengaruh terhadap variabel loyalitas pelanggan. Sehingga model regresi yang didapatkan layak digunakan untuk memprediksi. Maka dapat disimpulkan bahwa $\mathrm{H}_{\mathrm{o}}$ ditolak dan $\mathrm{H}_{\mathrm{a}}$ diterima.

\section{b. Hasil Uji Signifikan Parameter Individual (Uji Statistik t)}

Pengujian hipotesis secara parsial dimaksudkan untuk mengetahui ada atau tidaknya pengaruh variabel bebas secara parsial terhadap variabel terikat. Hasil hipotesis dalam pengujian ini adalah:

\section{Tabel 7} Hasil Uji t

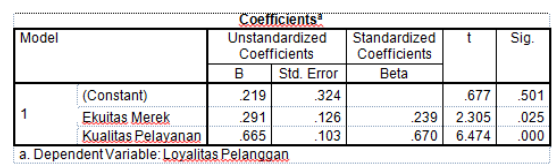

Page | 14 
JURNAL

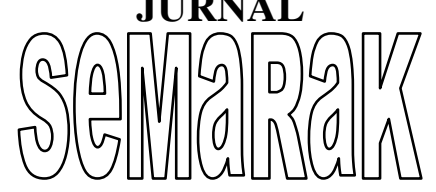

P-ISSN 2615-6849 E-ISSN 2622-3686

Jurnal Semarak,Vol. 1,No.2,Juni 2018 , Hal (1-20)

@ Prodi Manajemen Fakultas Ekonomi Universitas Pamulang
Berdasarkan tabel di atas hasil

Uji $\mathrm{t}$ di atas untuk mengetahui besarnya pengaruh masing-masing dari variabel independen secara parsial (individual) terhadap variabel dependen adalah sebagai berikut:

1) Menguji Signifiknasi Variabel Ekuitas Merek $\left(\mathrm{X}_{1}\right)$

Terlihat bahwa $t_{\text {hitung }}$ koefisien ekuitas merek adalah 2,305, Sedang $t_{\text {tabel }}$ bisa dihitung pada tabel t-test, dengan $\alpha=0.05$, karena digunakan hipotesis dua arah, ketika mencari $t_{\text {tabel}}$, nilai $\alpha$ dibagi 2 menjadi 0,025 dan $\mathrm{df}$ $=58$ (didapat dari rumus $\mathrm{n}-2$, dimana $\mathrm{n}$ adalah jumlah data, 60 $-2=58$ ). Didapat $t_{\text {tabel }}$ adalah 2,00 .

Variabel ekuitas merek memiliki nilai $p$-value $0,025<$ 0,05 artinya signifikan, sedangkan $t_{\text {hitung }}>t_{\text {tabel }},(2,305>$ 2,00), maka $\mathrm{H}_{\mathrm{a}}$ diterima dan $\mathrm{H}_{\mathrm{o}}$ ditolak, sehingga dapat disimpulkan bahwa koefisien ekuitas merek secara parsial berpengaruh signifikan terhadap loyalitas pelanggan. Hasil sesuai dengan penelitian yang dilakukan oleh Ainur Rofiq (2009) dengan judul "Peranan Ekuitas Merek Terhadap Loyalitas Pelanggan Industry Telepon Seluler" menunjukan Hasil analisis regresi bahwa ekuitas merek memiliki pengaruh yang signifikan terhadap loyalitas pelanggan telepon seluler. Di antara empat variabel ekuitas merek yang diteliti, persepsi kualitas tidak memiliki pengaruh yang signifikan terhadap loyalitas pelanggan. Sedangkan variabel yang memiliki pengaruh dominan terhadap loyalitas pelanggan adalah loyalitas merek.

2) Menguji Signifiknasi Variabel Kualitas Pelayanan $\left(\mathrm{X}_{2}\right)$

Terlihat bahwa $t_{\text {hitung }}$ untuk kualitas pelayanan adalah 6,474 , sedangkan $t_{\text {tabel }}$ bisa dihitung pada tabel t-test, dengan $\alpha=$ 0,05 , karena digunakan hipotesis dua arah, ketika mencari $t_{\text {tabel, }}$, nilai $\alpha$ dibagi dua menjadi 0,025 , dan $\mathrm{df}=58$ (didapat dari rumus $\mathrm{n}-2$, dimana $\mathrm{n}$ adalah jumlah data, $60-2=58$ ). Didapat $t_{\text {tabel }}$ adalah 2,00.

Variabel kualitas pelayanan memiliki nilai $p$-value $0,000<$ 0,05 artinya signifikan, sedangkan $t_{\text {hitung }}>t_{\text {tabel }},(6,474>$ 2,00), maka $\mathrm{H}_{\mathrm{a}}$ diterima dan $\mathrm{H}_{\mathrm{o}}$ ditolak, sehingga dapat disimpulkan bahwa koefisien kualitas pelayanan secara parsial berpengaruh signifikan terhadap 
JURNAL

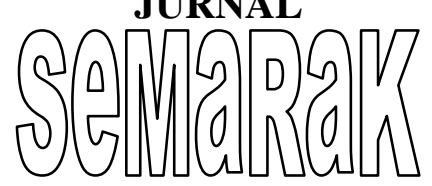

Jurnal Semarak,Vol. 1,No.2,Juni 2018 , Hal (1-20)

@ Prodi Manajemen Fakultas Ekonomi Universitas Pamulang

loyalitas pelanggan. Hasil sesuai dengan penelitian yang dilakukan oleh Partua Pramana Hamonangan Sinaga (2010), dengan judul Analisis Pengaruh Kualitas Pelayanan, Kepuasan Pelanggan, Dan Lokasi Terhadap Loyalitas Pelanggan (Studi Kasus Pada Warnet Chamber Semarang), metode yang digunakan menggunakan regresi linier berganda. Hasil menyatakan bahwa terdapat pengaruh baik secara parsial maupun simultan antara variabel Kualitas Pelayanan, variabel Kepuasan Pelanggan, dan Lokasi Terhadap Loyalitas Pelanggan.

\section{Hasil Uji Analisis Regresi Linier Berganda}

a. Hasil Uji Koefisien Determinasi (Adjusted $\mathbf{R}^{2}$ )

Hasil Koefisien determinasi (Adjusted $\mathrm{R}^{2}$ ) bertujuan untuk mengetahui seberapa besar kemampuan variabel independen (ekuitas merek dan kualitas pelayanan) menjelaskan variabel dependen (Loyalitas Pelanggan), adapun hasil uji determinasi adalah sebagai berikut:

Tabel 8

Hasil Koefisien Determinasi

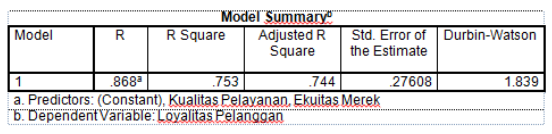

Tabel di atas didapat nilai Adjusted R Square sebesar 0,744 (74,4\%), Ini menunjukkan bahwa dengan menggunakan model regresi yang didapatkan dimana variabel independen yaitu ekuitas merek dan kualitas pelayanan memiliki pengaruh terhadap variabel loyalitas pelanggan sebesar 74,4\%. Sedangkan sisanya $25,6 \%$ dijelaskan dengan faktor atau variabel lain yang tidak diketahui dan tidak termasuk dalam analisis regresi ini seperti produk, brand image, kepuasan pelanggan dan lainya.

b. Hasil Koefisien Persamaan Regresi Linier Berganda

Adapun hasil regresi linier berganda pengaruh ekuitas merek dan kualitas pelayanan terhadap loyalitas pelanggan adalah sebagai berikut:

\section{Tabel 9}

Hasil Koefisien Persamaan Regresi Linier Berganda

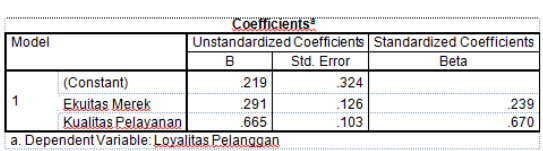

Pada output ini, dikemukakan nilai koefisien dari persamaan regresi. Dalam kasus ini, persamaan regresi berganda yang digunakan adalah:

$$
Y=a+b_{1} x_{1}+b_{2} x_{2}+\varepsilon i
$$


JURNAL

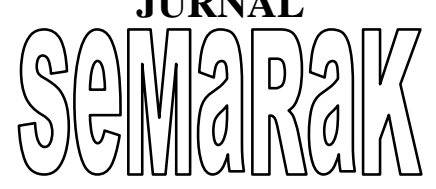

Jurnal Semarak,Vol. 1,No.2,Juni 2018 , Hal (1-20)

@Prodi Manajemen Fakultas Ekonomi Universitas Pamulang

bertambah sebesar 0,291 atau

Dimana:

Y : Loyalitas Pelanggan

a : konstanta

$b_{1}-b_{3} \quad$ : Koefisien Regresi

$\mathrm{X}_{1} \quad$ : Ekuitas Merek

$\mathrm{X}_{2} \quad$ : Kualitas Pelayanan

ci : Standar Error

Dari output didapatkan model persamaan regresi:

$Y=0,219+0,291 X_{1}+0,665 X_{2}+\varepsilon i$

Persamaan regresi berganda ini merupakan model terbaik, karena variabel independen yang dimasukkan dalam persamaan regresi merupakan variabel yang memberikan pengaruh terhadap variabel dependennya. Dari model regresi tersebut dapat dijabarkan sebagai berikut:

1) Konstanta sebesar 0,219 menyatakan bahwa jika ekuitas merek $\left(\mathrm{X}_{1}\right)$ dan kualitas pelayanan $\quad\left(\mathrm{X}_{2}\right) \quad$ dianggap konstant, maka loyalitas pelanggan (Y) akan meningkat sebesar 0,219 atau 21,9\%.

2) Koefisien regresi $X_{1}$ (ekuitas merek) sebesar $\quad 0,291$ menyatakan bahwa setiap kenaikan 1 unit (karena tanda + ) dari ekuitas merek, maka nilai $\mathrm{Y}$ (loyalitas pelanggan) akan
$29,1 \%$.

3) Koefisien regresi $X_{2}$ (kualitas pelayanan) sebesar 0,665 menyatakan bahwa setiap kenaikan 1 unit (karena tanda +) dari kualitas pelayanan, maka nilai Y (loyalitas pelanggan) akan bertambah sebesar 0,665 atau sebesar $66,5 \%$.

Persamaan model ini, menunjukkan bahwa pengaruh variabel ekuitas merek dam kualitas pelayanana berpengaruh positif terhadap loyalitas pelanggan. Berdasarkan nilai koefisien regresi pada setiap variabel, jika variabel bebas diurutkan dari pengaruh terbesar sampai pengaruh terkecil, maka pertama adalah kualitas pelayanan $\left(\mathrm{X}_{2}\right)$, kedua adalah ekuitas merek $\left(\mathrm{X}_{1}\right)$. Jadi berdasarkan nilai koefisien regresi variabel yang paling berpengaruh terhadap loyalitas pelanggan adalah variabel kualitas pelayanan, hal tersebut dilihat berdasarkan nilai standardizd coefficient beta terbesar yaitu sebesar 0,670 .

\section{KESIMPULAN DAN SARAN}

\section{A. Kesimpulan}

Berdasarkan pada hasil penelitian dan pembahasan mengenai analisis pengaruh ekuitas merek dan kualitas 


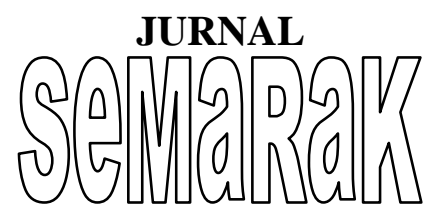

P-ISSN 2615-6849 E-ISSN 2622-3686

Jurnal Semarak,Vol. 1,No.2,Juni 2018 , Hal (1-20)

@Prodi Manajemen Fakultas Ekonomi Universitas Pamulang

pelayanan terhadap loyalitas pelanggan, maka penulis dapat menarik beberapa kesimpulan sebagai berikut:

1. Berdasarkan hasil uji Regresi berganda secara simultan ditemukan bahwa seluruh variabel independen yaitu ekuitas merek dan kualitas pelayanan dengan signifikan berpengaruh terhadap variabel loyalitas pelanggan, hasil terlihat berdasarkan nilai signifikan berada di bawah 0,05 .

2. Berdasarkan hasil uji Regresi berganda secara parsial ditemukan bahwa seluruh variabel independen (ekuitas merek dan kualitas pelayanan) berpengaruh secara signifikan loyalitas pelanggan.

3. Berdasarkan hasil uji regresi linier berganda kualitas pelayanan merupakan variabel yang paling berpengaruh terhadap loyalitas pelanggan terlihat berdasarkan nilai beta terbesar, yaitu sebesar 0,670 .

\section{B. Saran}

Berdasarkan analisa data dan pembahasan pada bab sebelumnya maka saran yang dapat disampaikan: gf

1. Bagi perusahaan

a. Agar melakukan peningkatan kualitas pelayanan dengan memberikan pelatihan bagi pegawai dalam melayani pasien.

b. Melakukan riset loyalitas pelanggan lebih lanjut, karena masih ada faktor-faktor lain yang belum dapat dijelaskan dalam penelitian ini.

2. Bagi akademisi

a. Bagi pihak yang ingin melakukan penelitian sejenis, disarankan untuk meneliti variabel-variabel lain selain ekuitas merek dan kualitas pelayanan. Karena dari penelitian ini diketahui 26,4\% masih ada faktorfaktor lain yang dapat mempengaruhi variabel loyalitas pelanggan.

b. Untuk memperkuat hasil penelitian serupa maka dianjurkan menambah sampel yang diteliti dan menjelaskan proses pengisian kuesioner dan dapat mendampingi responden ketika akan mengisi kuesioner tersebut.

\section{DAFTAR PUSTAKA}

Aaker, David. “Ekuitas Merek”, Edisi Bahasa Indonesia, Mitra Utama Jakarta, 2008.

Darmadi Durianto, Sugiarto, Tony Sitinjak, "Strategi Menaklukan pasar melalui riset ekuitas dan perilaku merek", Gramedia Pustaka Utama, Jakarta, 2001.

, Sugiarto; Lie Joko Budiman, "Brand Equity Ten: Strategi Memimpin Pasar", PT. Gramedia Pustaka Utama, Jakarta, 2004.

Ghozali, Imam. "Aplikasi Analisis Multivariat Dengan Program SPSS”, Badan Penerbit Universitas Dipenogoro, Semarang, 2005.

Griffin, Jill, "Customer Loyality Menumbuhkan Dan Mempertahankan 


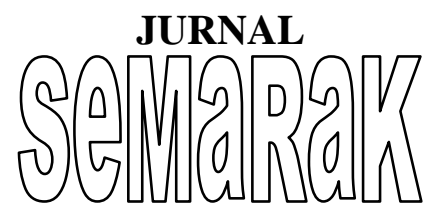

P-ISSN 2615-6849 E-ISSN 2622-3686

Jurnal Semarak,Vol. 1,No.2,Juni 2018 , Hal (1-20)

@ Prodi Manajemen Fakultas Ekonomi Universitas Pamulang
Kesetiaan Pelanggan”, Erlangga, Jakarta, 2001.

Hurriyati, Ratih, "Bauran Pemasaran Dan Loyalitas Konsumen, CV. Alfabneta, Bandung, 2008.

Istijanto, “Aplikasi Praktis Riset Pemasaran”, Gramedia Pustaka Utama, Jakarta, 2009.

Japarianto, Edwin, "Analisa Kualitas Pelayanan Sebagai Pengukur Loyalitas Pelanggan Hotel Majapahit Surabaya Dengan Pemasaran Relasional Sebagai Variabel Intervening", Skripsi Universitas Kristen Petra, Surabaya, 2010.

Kartono, “Analisis Elemen-elemen Ekuitas Merek Produk Minyak Pelumas Motor Merek Enduro $4 t$ (studi kasus pada mahasiswa universitas negeri semarang)", Karya ilmiah, Universitas Negeri Semarang, 2007.

Kheng, Lo Liang. "The impact of service quality on customer loyalty : A Study of Bank in Penang Malaysia", School of Management, University Sains Malaysia, Malaysia, 2010.

Kotler, P. "Marketing Management", Eleven Edition. New Jersey : Prentice Hall. 2003.

"Manajemen Pemasaran Jilid 2. Terjemahan Drs. Benyamin Molan. PT Indeks Kelompok Gramedia, 2004.

,"Manajemen Pemasaran”, Edisi Bahasa Indonesia, PT. Prenhalido Indonesia, Jakarta, 2009.

Mahrinasari MS, "Analisis Faktor Penentu Ekuitas Merek (Studi Pada Produk Tabungan, Tiga Bank Umum Terbesar Di Provinsi Lampung)”, Universitas Lampung, Lampung, 1997.

Malhotra, Naresh, “Marketing Research:an applied orientation, pearson education, inc", fifth edition, New Jearsey, USA, 2007.
Puspitasari, Anita; Wijaya, Petra Surya ,M, "Hubungan Antara Brand Equity dan Minat Konsumen: Perubahan Nama / Merek Panasonic dari Merek National", Jurnal Riset Manajemen dan Bisnis Vol.1 No.1, Juli, 2006.

Rahman, Arif. "Strategi Dahsyat Marketing Mix for Small Business".Transmedia, jakarta selatan, 2010.

Rangkuti, Freddy, "The Power of Brands; Teknik Mengelola Brand Equity dan Strategi Pengembangan Merek", Gramedia Pustaka Utama, Jakarta, 2002.

Rofiq, Ainur. "Peranan Ekuitas Merek Terhadap Loyalitas Pelanggan Industry Telepon Seluler", Jurnal Skripsi Universitas Brawijaya, Malang, 2009.

Santoso, Singgih, "Buku Latihan SPSS Statistik Parametrik”, PT. Elex Media Komputindo, Jakarta, 2000.

“Mastering SPSS Versi 19”, Elex Media Komputindo, Jakarta, 2011.

Simamora, "Aura Merek (7 langkah membangun merek yang kuat)",Gramedia Pustaka Utama, Jakarta, 2001.

Soemanagara, Kennedy, John. E; R Dermawan, "Marketing Communication”, 2006.

Sugiyono, "Metode Penelitian Bisnis", Edisi V, CV IKAPI, Bandung, 2005.

Sugiyono, "Metode Penelitian Bisnis", Edisi V, CV IKAPI, Bandung, 2010.

Temporal, Paul, "Branding di Asia, Penciptaan, Pembangunan, dan Manajemen Merek Asia Untuk Pasar Globe”, Batam: Interaksara, 2001.

Tjiptono, Fandy, Manajemen Jasa, Penerbit Andi, Yogyakarta, 2000.

"Pemasaran Jasa", Bayumedia Publishing, Malang, 2005. 
JURNAL

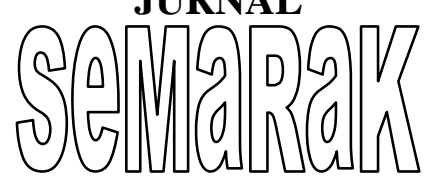

P-ISSN 2615-6849 E-ISSN 2622-3686

Jurnal Semarak,Vol. 1,No.2,Juni 2018 , Hal (1-20)

@Prodi Manajemen Fakultas Ekonomi Universitas Pamulang

Tjiptono, Fandy, Gregorius Chandra, "Service Quality Satisfaction" Andi, Yogyakarta, 2006.

Umar, Husein, "Riset Pemasaran dan Perilaku Konsumen", Gramedia Pustaka Utama, Jakarta, 2010.

Wahyuni, Ariani, "Manajemen Operasi Jasa Edisi Pertama", Graha Ilmu, Yogyakarta, 2009.

www.tangerangselatankota.go.id. 